\title{
Correspondence
}

ChINA \& WTO ReV. 2018:2; 337-350

http://dx.doi.org/10.14330/cwr.2018.4.2.06

pISSN 2383-8221 • elSSN 2384-4388

China and WTO Review

\section{Latest Chinese Investments in the South Pacific Area}

\author{
Yingying $\mathrm{Wu}^{*}$
}

\section{Overview}

In recent years, the Chinese government has been investing an enormous amount of money in infrastructure development across many of the island states in the area of the South Pacific. This essay will review such investments of China in Papua New Guinea, Fiji, Timor, Samoa, and Vanuatu (Annex) and further analyze the underlying rationale.

\section{Papua New Guinea}

Since 2012, China has made investments in Papua New Guinea ("PNG"), including Rim Nickel Mine, Laicheng Port Project, International Conference Center and Highland Highway Project ${ }^{1}$ In particular, the Agreement on Construction of Infrastructure, concluded between China and PNG on November 20, 2017, launched the highlands economic corridor development program, with USD 330 million from China for roads, agricultural parks, and other infrastructure. ${ }^{2}$ In June 2018, PNG and China signed a memorandum on the construction under the framework of the "Belt and Road" initiative. ${ }^{3}$ The Chinese government began to build a public road and repair the airport expressway in PNG in June 2018. ${ }^{4}$ The PNG National Power Grid Power Transmission and Transformation Project, the first energy cooperation project between China and PNG, was initiated

* Lecturer, School of International Law at China University of Political Science and Law. LL.M. (NYU), J.S.D. (Univ. of Illinois at Urbana-Champaign). ORCID: https://orcid.org/0000-0001-90947238. The author may be contacted at: wyyfada@163.com/Address: School of International Law, CUPL, No. 25, Xitucheng Road, Haidian District, Beijing, P.R. China 100088. 
by a Chinese company named TBEA Co. under the auspices of the Chinese government's preferential export buyer's credit funds. ${ }^{5}$ In 2018, two road projects in Mendicity, funded by the Asian Development Bank, are under construction by China Railway International Corporation. ${ }^{6}$ China Port Bay Company in PNG completed the APEC Roads Projects in August 2018.

\section{Map 1: South Pacific Islands Countries which welcome Chinese Investments}

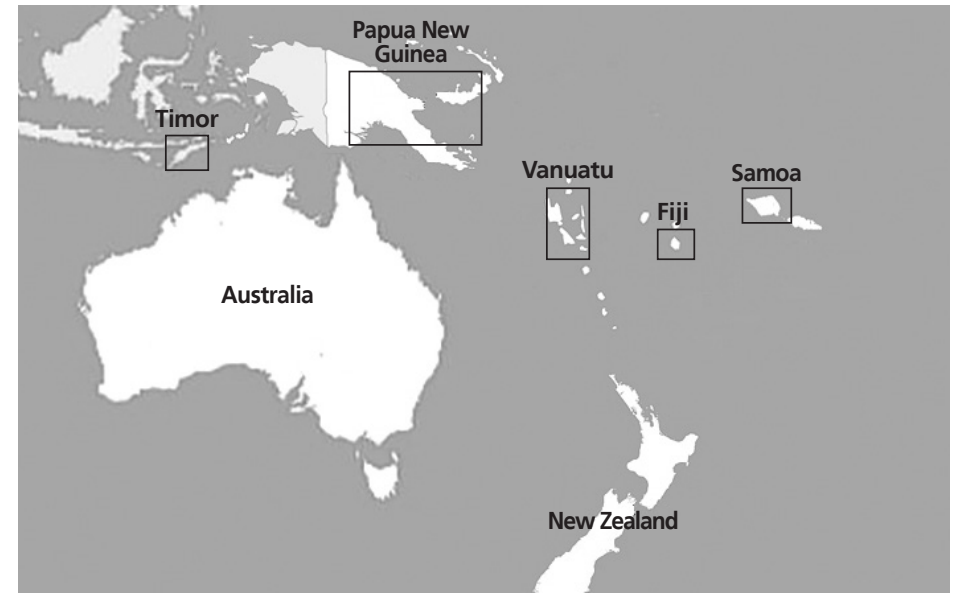

\section{Fiji}

China has become the largest investor in Fiji, accounting for 41-45 percent of all foreign investments in this country in the years of 2014, 2015, and 2016, respectively. ${ }^{8}$ The Stinson Bridge and Vatuwaka Bridge Project, which started in 2015 and was completed in 2017, was a free aid project of the Chinese government to Fiji, undertaken by China Railway Construction 14th Bureau Group Co., Ltd. ${ }^{9}$ The Somo Hydropower Project was started in 2013 and completed in 2016 on the third largest island in Fiji. As a free aid program of the Chinese government to Fiji, it was built by China Hunan Construction Engineering Group Corporation. ${ }^{10}$ Chinese preferential loan funded projects such as Naboaru Highway in 2016 and Buzabe Highway in 2015. Both of them were built by the China Railway First Bureau, which is a state-owned enterprise. ${ }^{11}$ In 2017, Zhejiang Wanguo 
Architectural Design Institute Co., Ltd invested in the Fiji Friendship Plaza project. ${ }^{12}$ Construction contracts cover hydropower stations, roads and bridges, sewage pipelines, and other projects. ${ }^{13}$ The China Railway One Aviation Institute is undertaking the iron ore port project in the second largest city of Fiji. It is currently the largest contracted project among Chinese companies in Fiji. ${ }^{14}$

In the agricultural sector, there are many oceanic fisheries companies owned by Chinese. ${ }^{15}$ The Fiji North Island Agricultural Development Assistance Project is a free aid project funded by China since 2015 that has been implemented by Shandong Foreign Economic Group. The project provides assistance to Fiji through rice breeding and cultivation demonstration, agricultural materials, and personnel training. ${ }^{16}$ Similar projects include China's assistance to Fiji's fungus technology cooperation project, which was completed in $2016 .{ }^{17}$ The Memorandum of Understanding on Agricultural Cooperation between China and Fiji furthered abovementioned cooperation. ${ }^{18}$

\section{Timor}

The Chinese government has provided free aid to fund the Ministry of Foreign Affairs Building, the Presidential Palace, and other projects in Timor. ${ }^{19}$ Chinese enterprises won bidding for the construction of the East Timor National Power Plant and the National Grid Project in 2008 with a contractual value of USD 360 million. ${ }^{20}$ There are also many contract projects undertaken by Chinese enterprises $^{21}$ such as Hunan Dongsheng Lubo Investment Group Co., Ltd. and Macao Deguang Electronics Development Co., Ltd. For example, these two firms signed an agreement to jointly invest in the construction of the East Timor Tibai Port Logistics. ${ }^{22}$

Under the framework of the China-Portugal Forum, Chinese agricultural enterprises have cultivated rice fields in East Timor. ${ }^{23}$ The project, which is named "China's East Timor Manatto Laraan South Fishery Port Aquaculture Park," was invested by Guangxi Yixin Fisheries Development Co., Ltd. It includes a fishing port construction, fishing boat shipyards, marine fishing operations, seafood sorting and processing plants, etc. ${ }^{24}$ In 2017 , the Shrimp Farming Project was invested and operated by China Longping High-Tech Co., Ltd. ${ }^{25}$ The Sino-East fishery cooperation on shrimp seedlings was launched in 2016, as well. ${ }^{26}$ 


\section{Samoa}

In 2011, the construction of Samoa government office building and the International Conference Center was undertaken by Shanghai Construction Engineering Group, with preferential loans from the Export-Import Bank of China. ${ }^{27}$ The two governments signed an agreement in 2012 for three projects, i.e., Ocean College of Samoa National University, restoring primary school, and the training center for the disabled. The projects were undertaken by Hunan Construction Engineering Group of China in 2014. ${ }^{28}$ In 2013, Chinese companies invested USD 13 million to build solar power plants in Samoa. ${ }^{29}$ In 2013, AVIC International Aviation Development Co., Ltd. signed a memorandum of cooperation with the Engineering Transportation and Infrastructure Department in Apia, Samoa. According to the memorandum, China would provide aircraft, technical training, spare parts, etc. for Samoa. ${ }^{30}$ In 2014, the two governments concerned signed a concessional loan agreement for upgrading and reconstructing the Rio International Airport, which was initially built under China's free aid. The Samoa National Medical Center, located in the capital, was completed in 2015 with preferential loan assistance from the Chinese government. ${ }^{31}$ China's assistance to the Samoa sports facilities maintenance and renovation project was completed in $2015 .^{32}$ In 2016, the first phase of the upgrade and reconstruction of the Valeoolo International Airport in Samoa was successfully completed by Shanghai Construction Engineering Group Co., Ltd. In the same year, the Agreement on Economic and Technical Cooperation between the two governments concerned was signed. ${ }^{33}$ In 2017, the Leone Bridge project, jointly funded by Australia and the World Bank, was completed by China Railway First Bureau Group Co., Ltd. ${ }^{34}$

\section{Vanuatu}

China's investment and aid in Vanuatu were started long before. In 2002, Zhongshui Group Ocean Shipping Co., Ltd. signed a bilateral fishery cooperation agreement with Vanuatu. It has sent 17 fishing boats to carry out tuna fishing business in the waters of the basin. ${ }^{35}$ The Project of office building of the Melanesia Pioneer Group Secretariat and the Port Vila China Medical Team Dormitory, were aided by China in 2007. The expansion project of Vanuatu Nantai University 
Emmaus, assisted and aided by China, was launched in $2013 .^{36}$ The new Economic and Technical Cooperation Agreement between China and Vanuatu was signed in 2015. ${ }^{37}$ Since then, China has launched aid projects including the parliament building project, the Nantai University law school building project, the Santotu dental clinic project, the Santonon Agricultural College, rice and vegetable planting technology cooperation projects, medical technology cooperation, table tennis technical cooperation projects, etc. ${ }^{38}$

\section{Analysis}

Examples provided in the article regarding Chinese investments in the South Pacific Area are not exhaustive. These islands, which are historically and geographically close to New Zealand, Australia, Indonesia, are less developed. Before China became a large investor in these islands, New Zealand and Australia had dominated the foreign investments there. For instance, Australia is a large investor in Papua New Guinea. New Zealand invested a lot in Samoa prior to Chinese investment in Samoa. Australia invested in gas and oil industry in Timor given that Australia imported gas from Timor through pipelines.

Both Australia and New Zealand not only invest but also provide aid out of politically driven motives. For instance, the establishment of Timor was supported by Australia against Indonesia in a geopolitical sense. Nevertheless, there are also some domestic issues that trouble these islands. Furthermore, as the sea level rises due to global warming, posing a threat to those islands, investment in this region is becoming less advantageous from an economic perspective. Hence, Australia and New Zealand may not be upset by Chinese investments in those islands in recent years. The other side of this equation is that Chinese investments have not encountered many difficulties from locals in these islands, and neighboring nations such as Australia, New Zealand, and Indonesia.

China has made investments in these islands through various means. Some projects are free aid by China to these islands. Others are funded with preferential loans from Chinese state-owned and controlled banks. Furthermore, the World Bank, the Asian Infrastructure and Investment Bank, the Asian Development Bank have funded these projects based on the membership of some of these islands countries. 
All these projects, no matter where the funding sources are deriving from, are primarily undertaken by Chinese companies, in particular, state-owned and controlled companies with free aid by the Chinese government, preferential loans, and construction contracts. These cover the areas of agriculture, fishing, infrastructure, roads, bridges, ports, airports, highways, agricultural technologies, hydropower, stations, and sewage pipelines. Also, the infrastructure projects, to some degree, facilitate and promote the development of tourism, which is one of the main pillar industries in these islands, such as Timor and Fiji. China seems to be interested in developing tourism in these islands, as well as building a close relationship with them in a geopolitical viewpoint. Chinese overseas investments is more likely to be accelerated in this region. 


\section{Annex}

\section{Chinese Investments in South Pacific Islands Countries}

\begin{tabular}{|c|c|c|c|}
\hline Countries & Major Investment Projects & Participants & $\begin{array}{c}\text { Size } \\
\text { (amount of fund: USD) }\end{array}$ \\
\hline \multirow{9}{*}{$\begin{array}{c}\text { Papua } \\
\text { New } \\
\text { Guinea }\end{array}$} & $\begin{array}{l}\text { Agreement on Construction } \\
\text { of Infrastructure (2017) }\end{array}$ & $\begin{array}{l}\text { Two governments of } \\
\text { China and PNG }\end{array}$ & 330 million \\
\hline & $\begin{array}{l}\text { PNG National Power } \\
\text { Grid Power Transmission } \\
\text { and Transformation } \\
\text { Project (2018) }\end{array}$ & TBEA Co. & $\begin{array}{l}\text { Preferential export } \\
\text { buyer' credit funds from } \\
\text { China (4 stations, Grid } \\
\text { Power Transmission } \\
\text { of } 189 \text { miles) }\end{array}$ \\
\hline & $\begin{array}{l}\text { Renovation of the } \\
\text { Expressway to the Airport, } \\
\text { and Build A Public Road } \\
\text { (2018) }\end{array}$ & $\begin{array}{c}\text { China Harbour } \\
\text { Engineering Company Ltd. }\end{array}$ & 1.2 million \\
\hline & $\begin{array}{l}\text { Two Roads Projects } \\
\text { in Mendi city }\end{array}$ & $\begin{array}{l}\text { China Railway } \\
\text { International Corporation }\end{array}$ & $\begin{array}{l}\text { Asian Development } \\
\text { Bank }\end{array}$ \\
\hline & $\begin{array}{l}\text { International Conference } \\
\text { Center (2012) }\end{array}$ & $\begin{array}{c}\text { China Jiangxi } \\
\text { International Economic } \\
\text { and Technological } \\
\text { Cooperation Company; } \\
\text { China Overseas } \\
\text { Holdings Limited; }\end{array}$ & Aid from China \\
\hline & $\begin{array}{l}\text { APEC Roads Projects } \\
\text { (2018) }\end{array}$ & $\begin{array}{c}\text { China Harbour } \\
\text { Engineering in PNG }\end{array}$ & Free aid from China \\
\hline & Laicheng Port Project & $\begin{array}{c}\text { China Harbour } \\
\text { Engineering Company } \\
\text { Ltd. }\end{array}$ & $\begin{array}{c}320 \text { million } \\
\text { ( } 72 \% \text { of funds comes } \\
\text { from the Asian } \\
\text { Development Bank, and } \\
\text { the rest from PNG } \\
\text { Government) }\end{array}$ \\
\hline & Rim Nickel Mine (2009) & $\begin{array}{l}\text { China Metallurgical Con- } \\
\text { struction Group }\end{array}$ & 1300 million \\
\hline & $\begin{array}{c}\text { Stinson Bridge and } \\
\text { Vatuwaka Bridge Project } \\
(2015-2017)\end{array}$ & $\begin{array}{l}\text { China Railway Construction } \\
\text { 14th Bureau Group Co., Ltd. }\end{array}$ & Free aid from China \\
\hline
\end{tabular}




\begin{tabular}{|c|c|c|c|}
\hline \multirow[t]{6}{*}{ Fiji } & $\begin{array}{l}\text { The Somo Hydropower } \\
\text { Project (2013-2016) }\end{array}$ & $\begin{array}{c}\text { China Hunan } \\
\text { Construction Engineering } \\
\text { Group Corporation }\end{array}$ & Free aid \\
\hline & $\begin{array}{l}\text { Naboaru Highway } \\
\text { (2016) }\end{array}$ & $\begin{array}{l}\text { China Railway } \\
\text { First Bureau }\end{array}$ & $\begin{array}{l}\text { Chinese preferential } \\
\text { loan; Highway is of } \\
70 \text { miles. }\end{array}$ \\
\hline & $\begin{array}{l}\text { Fiji Friendship Plaza } \\
\text { project (2017) }\end{array}$ & $\begin{array}{l}\text { Zhejiang Wanguo } \\
\text { Architectural Design } \\
\text { Institute Co., Ltd }\end{array}$ & $\begin{array}{l}30 \text { floors, with } 46000 \\
\text { square meters }\end{array}$ \\
\hline & $\begin{array}{l}\text { Iron ore port project in the } \\
\text { second largest city of Fiji. }\end{array}$ & $\begin{array}{c}\text { The China Railway One } \\
\text { Aviation Institute }\end{array}$ & $\begin{array}{l}\text { The largest Chinese } \\
\text { contracted project in Fiji }\end{array}$ \\
\hline & $\begin{array}{l}\text { Fiji North Island } \\
\text { Agricultural Development } \\
\text { Assistance Project (2015) }\end{array}$ & $\begin{array}{l}\text { Shandong Foreign } \\
\text { Economic Group }\end{array}$ & Free aid \\
\hline & Buzabe Highway (2015) & China Railway First Bureau & Chinese preferential loan \\
\hline
\end{tabular}

\begin{tabular}{l|c|c|c}
\hline Timor & $\begin{array}{c}\text { Construction of Ministry } \\
\text { of Foreign Affairs Building } \\
\text { and the Presidential Palace } \\
(2007-2009)\end{array}$ & $\begin{array}{c}\text { China Shandong } \\
\text { International Economic } \\
\text { \& Technical Cooperation } \\
\text { Group }\end{array}$ & Free aid \\
\hline $\begin{array}{c}\text { East Timor National Power } \\
\text { Plant and the National Grid } \\
\text { Project (2009) }\end{array}$ & $\begin{array}{c}\text { China Nuclear } \\
\text { E\&C Group }\end{array}$ & 360 million \\
\hline \multirow{2}{*}{$\begin{array}{c}\text { East Timor Tibai Port } \\
\text { Logistics (2017) }\end{array}$} & $\begin{array}{c}\text { Hunan Dongsheng Lubo } \\
\text { Investment Group Co., Ltd.; } \\
\text { Macao Deguang Electronics } \\
\text { Development Co., Ltd. }\end{array}$ & \\
\hline $\begin{array}{c}\text { Laraan South Fishery Port } \\
\text { Aquaculture Park (2017) }\end{array}$ & $\begin{array}{c}\text { Guangxi Yixin Fisheries } \\
\text { Development Co., Ltd }\end{array}$ & 400 million \\
\hline $\begin{array}{c}\text { Shrimp Farming Project } \\
\text { (2017) }\end{array}$ & $\begin{array}{c}\text { China Longping } \\
\text { High-Tech Co., Ltd. }\end{array}$ & \\
\hline
\end{tabular}




\begin{tabular}{|c|c|c|c|}
\hline Samoa & $\begin{array}{l}\text { Leone Bridge project } \\
\qquad \text { (2017) }\end{array}$ & $\begin{array}{l}\text { China Railway First } \\
\text { Bureau Group Co., Ltd. }\end{array}$ & $\begin{array}{l}4.3 \text { million } \\
\text { (funded by Australia } \\
\text { and World Bank) }\end{array}$ \\
\hline & $\begin{array}{l}\text { the first phase of the upgrade } \\
\text { and reconstruction of } \\
\text { the Valeoolo International } \\
\text { Airport in Samoa (2016) }\end{array}$ & $\begin{array}{l}\text { Shanghai Construction } \\
\text { Engineering Group } \\
\text { Co., Ltd }\end{array}$ & \\
\hline & $\begin{array}{l}\text { The Samoa National } \\
\text { Medical Center (2015) }\end{array}$ & $\begin{array}{l}\text { Shanghai Construction } \\
\text { Group }\end{array}$ & $\begin{array}{c}\text { Preferential loan } \\
\text { assistance from the } \\
\text { Chinese government. }\end{array}$ \\
\hline & $\begin{array}{c}\text { Sports Facilities } \\
\text { Maintenance and } \\
\text { Renovation Project (2015) }\end{array}$ & $\begin{array}{l}\text { Shanghai Construction } \\
\text { Group }\end{array}$ & Free Aid \\
\hline & $\begin{array}{l}\text { Upgrading and Reconstructing } \\
\text { the Rio International Airport } \\
\text { (2015) }\end{array}$ & $\begin{array}{l}\text { Shanghai Construction } \\
\text { Group }\end{array}$ & $\begin{array}{l}\text { Free aid for construction; } \\
\text { concessional loan at } \\
\text { governmental level for } \\
\text { upgrading (50 million) }\end{array}$ \\
\hline & $\begin{array}{l}\text { memorandum of cooperation } \\
\text { with the Engineering } \\
\text { Transportation and } \\
\text { Infrastructure Department } \\
\text { in Apia, Samoa (2013) }\end{array}$ & $\begin{array}{l}\text { AVIC International } \\
\text { Aviation Development } \\
\text { Co., Ltd. }\end{array}$ & $\begin{array}{l}\text { China would provide } \\
\text { aircraft, technical } \\
\text { training, spare parts, } \\
\text { etc. to the Samoa }\end{array}$ \\
\hline & $\begin{array}{c}\text { The Construction of Solar } \\
\text { Power Plants in Samoa (2013) }\end{array}$ & $\begin{array}{l}\text { China Fujian New Energy } \\
\text { Development Ltd. Co. } \\
\text { (a subsidiary of Guodian } \\
\text { Power Development) }\end{array}$ & 13 million \\
\hline & $\begin{array}{c}\text { Construction of } \\
\text { Ocean College of Samoa } \\
\text { National University, } \\
\text { Renovation of primary school, } \\
\text { and the training center for the } \\
\text { disabled (2012-2014) }\end{array}$ & $\begin{array}{l}\text { Hunan Construction Engi- } \\
\text { neering Group } \\
\text { of China }\end{array}$ & $\begin{array}{l}\text { Governmental } \\
\text { agreements }\end{array}$ \\
\hline & $\begin{array}{c}\text { Construction of Samoa } \\
\text { government office } \\
\text { building and the International } \\
\text { Conference Center (2011) }\end{array}$ & $\begin{array}{c}\text { Shanghai Construction Engi- } \\
\text { neering Group }\end{array}$ & $\begin{array}{l}\text { Preferential loans } \\
\text { from the Export-Import } \\
\text { Bank of China }\end{array}$ \\
\hline
\end{tabular}




\begin{tabular}{l|c|c|c}
\hline Vanuatu & $\begin{array}{c}\text { Bilateral fishery } \\
\text { cooperation agreement (2002) }\end{array}$ & $\begin{array}{c}\text { Zhongshui Group Ocean } \\
\text { Shipping Co., Ltd }\end{array}$ & Aid from China \\
\hline $\begin{array}{c}\text { Project of office building of } \\
\text { he Melanesia Pioneer Group } \\
\text { Secretariat and the } \\
\text { Port Vila China Medical } \\
\text { Team Dormitory (2007) }\end{array}$ & $\begin{array}{c}\text { Expansion Project of } \\
\text { Vanuatu Nantai University } \\
\text { Emmaus (2013) }\end{array}$ & Aid from China \\
\hline $\begin{array}{c}\text { Construction and Design } \\
\text { of National Conference } \\
\text { Center (2011) }\end{array}$ & Aid from China \\
\hline $\begin{array}{c}\text { The new Economic and } \\
\text { Technical Cooperation } \\
\text { Agreement between China } \\
\text { and Vanuatu (2015) }\end{array}$ & & \\
\hline
\end{tabular}

Source: Compiled by the author.

Note: The table is based on all information available to the public. Some information, however, is limited or missing, such as the companies that participates the project and the size of the project. 


\section{REFERENCES}

1. Papua New Guinea Prime Minister of PNG Highly Appreciated the China-Pacific Islands Forum, and Would Like to Deepen Cooperation with China [巴新总理表示参加第二届中太 论坛富有成果 巴新方希望加强与中国合作], Nov. 20, 2013, available at http://pg.mofcom. gov.cn/article/jmxw/201311/20131100396635.shtml; Counsellor of the Embassy of the PRC Visited Laicheng Port Project in PNG [我处参赞访问巴新莱城港潮汐码头项目], Economic and Commercial Counsellor's Office of the Embassy of the PRC (“ECCOE") in PNG, May 2, 2013, available at http://pg.mofcom.gov.cn/article/jmxw/201305/20130500109761.shtml; The Opening Ceremony of International Conference Center Project Aided by China was Held [中国援巴新国际会议中心项目顺利举行开工典礼], Nov. 7, 2012, available at http://pg.mofcom. gov.cn/article/jmxw/201211/20121108423086.shtml (all last visited on Aug. 9, 2018).

2. See China Invests in Infrastructure in the Pacific Island Countries, GuANCHAZHE [观察者], Nov. 22, 2017, available at $\mathrm{https}$ //www.guancha.cn/Neighbors/2017_11_21_435847.shtml?s =fwckhfbt (last visited on Aug. 8, 2018).

3. Premier O'Nell Visited and China and PNG Established a Comprehensive Strategic Partnership [奥尼尔总理成功访华, 中巴新建立全面战略伙伴关系], ECCOE in PNG, July 3, 2018, available at http://pg.mofcom.gov.cn/article/jmxw/201807/20180702762201.shtml (last visited on Aug. 9, 2018).

4. The Opening Ceremony of the Expressway Maintenance and Reconstruction Project of the Aided New Airport in PNG was Successfully held [援巴新机场快速路维修改造项目1.2公里单 侧道路通车仪式成功举行], ECCOE in PNG, June 21, 2018, available at http://pg.mofcom.gov. cn/article/jmxw/201806/20180602757371.shtml (last visited on Aug. 9, 2018).

5. The Opening Ceremony for the First Phase of the PNG National Power Grid was Successfully Held [巴新国家电网一期项目开工仪式顺利举行], ECCOE in PNG, June 12, 2018, available at http://www.mofcom.gov.cn/article/i/jyj1/1/201806/20180602754505.shtml (last visited on Aug. 7, 2018).

6. A riot occurred in Mendi, South Province in PNG, and the government announced a state of emergency [巴新南高地省门迪发生暴乱, 政府宣布国家实施紧急状态], ECCOE in PNG, June 21, 2018, available at http://www.mofcom.gov.cn/article/i/jyj1/1/201806/20180602757366. shtml (last visited on Aug. 9, 2018).

7. The Opening of One Lane of the APEC Roads Projects Funded by China [援巴新APEC道路项 目左幅半侧道路全面开通], ECCOE in PNG, Aug. 3, 2018, available at http://pg.mofcom.gov. cn/article/jmxw/201808/20180802772486.shtml (last visited on Aug. 9, 2018).

8. China Ranked as the Top One Investor in Fiji, ECCOE in Fiji [中国对斐济投资项目数居首 位], ECCOE in Fiji, Jan. 11, 2017, available at http://www.mofcom.gov.cn/article/i/jyjl/1/ 201701/20170102499138.shtml (last visited on Aug. 9, 2018).

9. The Opening Ceremony of China's Aid to Fiji Stinson Bridge and Vatuwaka Bridge Project was Held [中国援斐济斯丁森桥和瓦图瓦卡桥项目举行通车仪式], ECCOE in Fiji, Jan. 11, 2018, 
available at http://www.mofcom.gov.cn/article/i/jyj1/1/201801/20180102697342.shtml (last visited on Aug. 9, 2018).

10. Fiji Somosomo Hydropower Stateion Aided by China was Officially Opened [中国援斐济 索摩索摩水电站正式启用], ECCOE in Fiji, Mar. 10, 2017, available at http://www.mofcom. gov.cn/article/i/jyjl/1/201703/20170302531495.shtml (last visited on Aug. 9, 2018).

11. Ambassador Zhang Ping and Prime Minister of Fiji Attended the Opening Ceremony of the Nabwaru Highway of the Chinese Government Excellent Loan Project [张平大使与斐济总 理出席中国政府优贷项目纳布瓦鲁公路通车仪式], ECCOE in Fiji, Jan. 15, 2016, available at http://www.mofcom.gov.cn/article/i/jyj1/1/201601/20160101234963.shtml (last visited on Aug. 9, 2018).

12. Ambassador Zhang Ping Attended the Opening Ceremony of the Friendship Square of the United Nations [张平大使出席万国友谊广场开工仪式], ECCOE in Fiji, Aug. 17, 2017, available at http://www.mofcom.gov.cn/article/i/jyjl/1/201708/20170802628246.shtml (last visited on Aug. 7, 2018).

13. Briefing on China-Philippines Economic and Trade Cooperation [中斐经贸合作简况], ECCOE in Fiji, July 22, 2015, available at http://fj.mofcom.gov.cn/article/zxhz/hzjj/201507/ 20150701054592.shtml (last visited on Aug. 9, 2018).

14. Counselor Li Zhi Went to the China Iron and Steel Institute's Iron Ore Dock Project to Investigate and Donduct Safety Inspections [李智参赞赴中交一航院铁矿砂码头项目调研并开 展安全检查], ECCOE in Fiji, Mar. 20, 2018, available at http://www.mofcom.gov.cn/article/ i/jyj1/1/201803/20180302720023.shtml (last visited on Aug. 9, 2018).

15. Vice Minister Yu Kangzhen from the Ministry of Agriculture of China Led a Delegation to Visit Fiji [中国农业部于康震副部长率团访问斐济], ECCOE in Fiji, Sept. 12, 2017, available at http://www.mofcom.gov.cn/article/i/jyj1/1/201709/20170902642360.shtml (last visited on Aug. 9, 2018).

16. Fiji President Conroe visited China's Aided Rice Technology Cooperation Project [斐济总 统孔罗特参观中国援斐水稻技术合作项目], ECCOE in Fiji, July 14, 2016, available at http:// www.mofcom.gov.cn/article/i/jyj1/1/201607/20160701358633.shtml (last visited on Aug. 9, 2018).

17. The Third Meeting of the China-Africa Joint Agriculture Committee was held in Suva [中斐 农业联委会第三次会议在苏瓦举行], ECCOE in Fiji, Oct. 10, 2016, available at http://www. mofcom.gov.cn/article/i/jyj1/1/201610/20161001405921.shtml (last visited on Aug. 9, 2018).

18. Id.

19. Online communication with the Counselor of the Chinese Embassy in East Timor [在线 访谈驻东帝汶经商参处], PRC Ministry of Commerce, Mar. 29, 2010, available at http:// interview.mofcom.gov.cn/detail/201605/1548.html (last visited on Aug. 9, 2018).

20. Brief Introduction to China and East Timor Bilateral Economic and Trade Cooperation, Department of Asian affairs [中国东帝汶双边经贸合作简况], Department of Asian Affairs, PRC Ministry of Commerce, Feb. 5, 2016, available at http://yzs.mofcom.gov.cn/article/ 
t/201602/20160201252495.shtml; The Opening Ceremony of National Power Plant in East Timor [东帝汶电厂项目举行开工仪式], ECCOE in Timor-Leste, Jan. 16, 2010, available at http://easttimor.mofcom.gov.cn/article/jmxw/201002/20100206776789.shtml (all last visited on Aug. 9, 2018).

21. See Fujian Enterprises Pay Close Attention to the 'Belt and Road' Opportunity to Promote International Capacity Cooperation between China and East Timor [福建企业紧抓 “一 带一路” 机遇 推进国际产能合作], ChinA News, Oct. 30, 2017, available at http://www. chinanews.com/cj/2017/10-25/8360052.shtml (last visited on Aug. 9, 2018).

22. Xu Dazhe Attended the Symposium of Well-known figures in the Macao Business Community, Ministry of Commerce [许达哲出席澳门工商界知名人士座谈会], PRC Ministry of Commerce, Apr. 28, 2017, available at http://www.mofcom.gov.cn/article/difang/201704/ 20170402567087.shtml (last visited on Aug. 9, 2018).

23. Deepen the Cooperation between China and Portugal Forum to Achieve Mutual Benefits [深 化中葡论坛机制合作 实现互利共赢], Department of Taiwan, Hong Kong and Macao Affairs, PRC Ministry of Commerce, June 19, 2018, available at http://tga.mofcom.gov.cn/article/ zwyw/zyjh/201806/20180602759406.shtml (last visited on Aug. 9, 2018).

24. The Project of Guangxi Enterprises Investing in the East Timor Fishery Park is Underway Smoothly [广西企业投资东帝汶渔业园区项目进展顺利], PRC Ministry of Commerce, Nov. 23, 2017, available at http://www.mofcom.gov.cn/article/resume/n/201711/2017 1102675221.shtml (last visited on Aug. 9, 2018).

25. Chinese Companies Hold Harvest Celebrations in the First Shrimp Farming Project in East Timor [中国企业在东帝汶首个对虾养殖项目举行收获庆典活动], ECCOE in East Timor, Jan. 15, 2017, available at http://easttimor.mofcom.gov.cn/article/jmxw/201701/ 20170102501581.shtml (last visited on Aug. 9, 2018).

26. Ambassador Liu Hongyang Attended the China-East Timor Fisheries Cooperation Shrimp Launching Ceremony [刘洪洋大使出席中国-东帝汶渔业合作对虾虾苗投放仪式], Embassy of the PRC in the Democratic Republic of Timor-Leste, Oct. 1, 2016, available at http:// tl.china-embassy.org/chn/sgdt/t1403158.htm (last visited on Aug. 9, 2018).

27. Assisting the Completion of the Samoan Government official Building [我优贷援萨摩亚政 府办公楼竣工], ECCOE in Samoa, Nov. 5, 2011, available at http://www.mofcom.gov.cn/ aarticle/i/jyjl/1/201111/20111107815681.html (last visited on Aug. 9, 2018).

28. Wang Xuefeng, Ambassador of Samoa, and Minister of Education, Sports and Culture Signed the Certificate for China's Aid Project [驻萨摩亚大使王雪峰与萨教育体育文化部部 长签署中国援萨项目交接证书], ECCOE in Samoa, Dec. 24, 2015, available at http://www. mofcom.gov.cn/article/i/jyj1/1/201512/20151201218068.shtml (last visited on Aug. 9, 2018).

29. Introduction to Samoa's Investment [萨摩亚投资领域简介], ECCOE in Samoa, Nov. 7, 2014, available at $\mathrm{http}: / / \mathrm{www} . m o f c o m . g o v . c n / a r t i c l e / \mathrm{i} / \mathrm{dxfw} / \mathrm{nbgz} / 201411 / 20141100788217 . \mathrm{shtml}$ (last visited on Aug. 9, 2018).

30. AVIC International and the Government of Samoa signed a Memorandum of Cooperation [ 
中航国际公司与萨政府签署合作备忘录], ECCOE in Samoa, Dec. 24, 2013, available at http:// www.mofcom.gov.cn/article/i/jyj1/1/201312/20131200436126.shtml (last visited on Aug. 9, 2018).

31. Completion of the Second Phase of the Aided Samoa Medical Center [援萨摩亚医疗中心二 期工程竣工移交], Department of Foreign Assistance, PRC Ministry of Commerce, Nov. 4, 2015, available at http://yws.mofcom.gov.cn/article/b/201511/20151101155012.shtml (last visited on Aug. 9, 2018).

32. Successful Transfer of the Sports Facilities Maintenance and Reconstruction Project [援萨摩亚体 育设施维修改造项目顺利移交], Department of Foreign Assistance, PRC Ministry of Commerce, Dec. 21, 2015, available at http://yws.mofcom.gov.cn/article/b/201512/20151201214898. shtml (last visited on Aug. 9, 2018).

33. Wang Xuefeng, Ambassador of Samoa, and Prime Minister Tuilaepa signed the Agreement on Economic and Technical Cooperation between the Government of the PRC and the Government of the Independent State of Samoa [驻萨摩亚大使王雪峰同萨总理图伊拉埃帕 签署中萨经济技术合作协定], ECCOE in Samoa, Jan. 19, 2016, available at http://www. mofcom.gov.cn/article/i/jyj1/1/201610/20161001409191.shtml (last visited on Aug. 9, 2018).

34. Completion of the Leone Bridge Project in Samoa [萨摩亚Leone桥梁项目竣工], ECCOE in Samoa, July 3, 2017, available at http://www.mofcom.gov.cn/article/i/jyj1/1/201707/ 20170702614022.shtml (last visited on Aug. 9, 2018).

35. Introduction of Cooperation [合作简介], ECCOE in Vanuatu, Sept. 2, 2015, available at http://vu.mofcom.gov.cn/article/zxhz/hzjj/200203/20020300009825.shtml (last visited on Aug. 9, 2018).

36. Id.

37. Ambassador Xie Bohua of Vanuatu and Vanuatu Prime Minister Kilman Sign New Economic and Technical Cooperation Agreement [驻瓦努阿图大使谢波华与瓦努阿图总理基尔曼签署新的 经济技术合作协定], ECCOE in Vanuatu, Sept. 22, 2015, available at http://www.mofcom.gov. cn/article/i/jyjl/1/201509/20150901118841.shtml (last visited on Aug. 9, 2018).

38. Supra note 35. 